Mukhlishotul Jannah

\title{
PENGARUH PEMBERIAN INSENTIF TERHADAP KINERJA KARYAWAN
}

\begin{abstract}
Abstrak
Tujuan utama dari suatu bisnis adalah mendapatkan keuntungan. Sedangkan yang memberikan keuntungan bukan hanya pelanggan, tetapi ada sumber daya manusia yang merupakan faktor produksi yang bisa membuat keinginan pelanggan bisa terpenuhi. Di sinilah peran sumber daya manusia, sejak bahan baku yang masih berada di suplier, dalam proses produksi, hingga barang ke tangan pelanggan.

Di sisi lain perusahaan harus menyadari bahwa karyawan sebagai mahluk sosial pada dasarnya memiliki berbagai macam kebutuhan yang semakin lama semakin bertambah. Untuk itu perusahaan harus memperhatikan kesejahteraan baik berupa materi maupun non materi kepada karyawan beserta keluarganya. Hal ini dapat membuat para pegawai bersemangat dalam bekerja, terciptanya ketenangan, loyal terhadap perusahaan dan mau memberikan segala kemampuannya dalam bekerja, sehingga kinerja karyawan menjadi lebih optimal.

Dalam meningkatkan kinerja karyawan diperlukan analisis terhadap faktorfaktor yang mempengaruhinya dengan memperhatikan kebutuhan dari para pegawai, diantaranya adalah upah atau gaji dan insentif. Insentif dapat digunakan sebagai salah satu alat untuk memotivasi karyawan dalam rangka untuk meningkatkan kinerja mereka dan merangsang para karyawan untuk berperan aktif dalam pencapaian tujuan perusahaan.
\end{abstract}

Kata Kunci: Insentif, kinerja, karyawan, perusahaan.

\section{Pendahuluan}

Perusahaan harus menyadari bahwa karyawan sebagai mahluk sosial pada dasarnya memiliki berbagai macam kebutuhan yang semakin lama semakin bertambah, untuk itu perusahaan harus memperhatikan kesejahteraan baik berupa material maupun non material kepada karyawan beserta keluarganya. Hal ini akan dapat membuat para karyawan bersemangat dalam bekerja, terciptanya ketenangan, bersifat loyal terhadap perusahaan dan mau memberikan segala kemampuannya dalam bekerja, sehingga kinerja karyawan menjadi lebih optimal. Dalam suatu perusahaan, bentuk kesejahteraan yang di dalamnya termasuk insentif yang diberikan kepada karyawan tergantung pada berbagai macam faktor, sebagai contoh pimpinan otoriter akan berbeda dengan pimpinan yang partisipatif dalam memberikan insentif 
kepada karyawan. Bahkan ada juga insentif yang diterima hanya didasarkan pada Performance Review.

Tenaga kerja atau sumber daya manusia merupakan faktor yang mutlak diperlukan dalam suatu organisasi, baik pada instansi pemerintah, perusahaan perusahaan atau usaha-usaha sosial untuk mendapatkan suatu balas jasa/imbalan tertentu. Tenaga kerja atau SDM dapat diartikan sebagai buruh, karyawan, pekerja, pegawai, pada hakekatnya mempunyai maksud yang sama. Manajemen sumber daya manusia merupakan sarana untuk meningkatkan kualitas manusia, dengan memperbaiki sumber daya manusia, meningkatkan pula kinerja dan daya hasil organisasi, sehingga dapat mewujudkan karyawan yang memiliki disiplin dan kinerja yang tinggi.

Kinerja karyawan dipengaruhi oleh berbagai macam ciri pribadi dari masingmasing individu, dalam praktiknya penilaian prestasi atau kinerja karyawan yang ditemui banyak yang tidak obyektif. Misalnya penempatan pegawai yang tidak sesuai dengan kemampuannya, bekerja puluhan tahun dengan pekerjaan yang sama. Belum lagi adanya pembatasan usia bagi kegiatan tertentu, misalnya batasan usia untuk training ke luar negeri. Mengapa tidak ditinjau dari segi manfaat yang diterima dari training tersebut, bisa tidaknya diterapkan di tempat kerja. Lebih penting lagi adalah bagaimana kemampuan belajar atau menyerap pelajaran seseorang. No One is too old to Learn. Tidak ada orang yang terlalu tua untuk belajar.

Dikotomi-dikotomi seperti ini bisa membuat pekerja kurang bergairah, bahkan apatis. Ini melanggar hak-hak asasi pekerja. Penulis banyak bertemu dengan mereka yang berusia lanjut (di atas 60 tahun) yang masih produktif. Banyak ide mereka untuk perbaikan bangsa ini. Perlunya pembinaan dan pengembangan sebagai salah satu kegiatan dalam rangka penyesuaian diri dengan perubahan dan perkembangan karyawan, yang dapat menciptakan karyawan yang berkualitas dan memiliki prestasi kerja yang tinggi. Setelah itu perusahaan perlu melakukan penilaian prestasi kerja dan memberikan umpan balik atas kinerja karyawan sebagai pedoman bagi tindakantindakan di masa yang akan datang. Perusahaan juga perlu melakukan evaluasi terhadap penilaian tersebut.

Upah atau gaji dan insentif merupakan suatu imbalan yang diterima seseorang dalam hubungan kerja yang berupa uang, melalui perjanjian kerja. Upah atau gaji sebenarnya merupakan imbalan atas prestasi karyawan, semakin tinggi prestasi karyawan seharusnya semakin besar pula gaji termasuk insentif yang akan diterima. Prestasi ini biasanya dinyatakan sebagai kinerja maupun produktivitas.

Kinerja merupakan hasil kerja yang dicapai oleh individu yang disesuaikan dengan peran atau tugasnya yang dihubungkan dengan suatu ukuran nilai tertentu dari perusahaan dimana individu tersebut bekerja. Dalam penentuan kinerja, ada tiga indikator yang perlu diperhatikan, yaitu: keterampilan yang meliputi kemampuan dan kecakapan individu, tingkat upaya yang diperlihatkan untuk menyelesaikan pekerjaan yang berkaitan dengan tugas karyawan, dan kondisi eksternal dan internal yang 
mendukung produktivitas karyawan. Hal ini menunjukkan bahwa kinerja bergantung pada ketiga faktor tersebut, jika salah satu cukup atau tidak mendukung satu dengan yang lain maka kinerja akan terganggu.

Permasalahan yang timbul berkaitan dengan kinerja karyawan salah satunya adalah dalam penentuan upah atau gaji dan intensif karyawan yang masih ditemukan ketidaksesuaian antara keahlian atau ketrampilan yang dimiliki dengan upah atau gaji yang diberikan sehingga mengakibatkan sikap dan minat karyawan kurang merespon terhadap tugas-tugas yang diberikan oleh perusahaan. Permasalahan lain yang timbul akibat kurang sesuainya dalam penempatan tenaga kerja atau karyawan diantaranya kebutuhan atau pemberian upah insentif yang kurang maksimal, hal ini terlihat dari masih adanya karyawan yang kurang bersemangat dalam bekerja serta secara individu kurang mempunyai minat, sikap dan kebutuhan dalam bekerja karena kurang sesuainya imbalan atau insentif yang diberikan sehingga akan berakibat pada kinerja yang dicapai kurang maksimal.

Kurang maksimalnya kinerja dari karyawan antara lain dapat terlihat dari rendahnya motivasi untuk berprestasi yang ditunjukkan oleh beberapa karyawan yang bekerja hanya kalau ada tugas dari pimpinan atau perusahaan, mereka tidak secara mandiri menyelesaikan pekerjaan dengan baik dan cepat. Keadaan seperti ini menyebabkan pelaksanaan pekerjaan kebanyakan dilakukan oleh orang tertentu saja yaitu karyawan yang berhadapan langsung dengan bidang tugas dan wewenangnya. Permasalahan-permasalahan tersebut mencerminkan bahwa masih diperlukan adanya upaya untuk mencapai peningkatan kinerja karyawan yang antara lain dipengaruhi oleh pemberian upah dan insentif kepada karyawan yang dapat menyelesaikan pekerjaan dengan baik dan cepat.

Dari uraian di atas, artikel ini fokus untuk meneliti apakah ada pengaruh antara pemberian insentif terhadap kinerja karyawan? Untuk menjawab pertanyaan tersebut, penulis menyusun dugaan sementara bahwa ada pengaruh positif dan signifikan antara pemberian insentif terhadap kinerja karyawan.

\section{Landasan Teori}

\section{Pengertian Insentif}

Ada beberapa pengertian insentif yang dikemukakan oleh para ahli. Agar pengertian insentif karyawan/kompensasi pelengkap/indirect compensation/welfare employee/fringe benefit, jelas, penulis mengemukan definisi-definisi dibawah ini.

Menurut Hasibuan insentif karyawan adalah balas jasa pelengkap (material dan

non material) yang dberikan berdasarkan kebijaksanaan. Tujuannya untuk mempertahankan dan memperbaiki kondisi fisik dan mental karyawan agar produktifitas kerjanya meningkat.

1

Andrew F. Sikula mengemukakan bahwa "indirect compesation are reimbursment recieved by employee in form than direct wage or salary". 
Berdasarkan pendapat Andrew F Sikula, kompensasi tidak langsung adalah balas jasa yang diterima oleh pekerja dalam bentuk selain upah atau gaji langsung. ${ }^{2}$

Dale Yoder mengemukakan bahwa "Benefits may be regarded as the more tangible financial contribution to employees. Special payment to those who are ill, contribution to employees saving, distribution of stock, insurance, hospitalization, and private pension for simple". Menurut Dale Yoder, insentif dapat dipandang sebagai uang bantuan lebih lanjut kepada karyawan. Terutama kepada mereka yang sakit, uang bantuan untuk tabungan karyawan, pembagian berupa saham, asuransi perawatan di rumah sakit, dan pensiun. ${ }^{3}$

Selanjutnya Dale Yoder menyatakan bahwa "Service, in this distinction, are action taken for the assistance or aid of the employees, such as the provision of legal aid or personal concelling or recreational advine guidance." Menurut Dale Yoder, pelayanan adalah tindakan yang diambil untuk menolong atau membantu para karyawan seperti pemberian bantuan hukum atau nasehat dibidang kepegawaian, kesenian, olah raga dan lain sebagainya. ${ }^{4}$

Veithzal Rivai mengemukakan bahwa kompensasi tidak langsung (Fringe Benefit) merupakan kompensasi tambahan yang diberikan berdasarkan kebijakan perusahaan terhadap semua karyawan sebagai upaya meningkatkan program insentif karyawan. Contohnya berupa fasilitas-fasilitas, seperti asuransi, tunjangan, uang pensiun, dan lain-lain. ${ }^{5}$

\section{Persamaan dan Perbedaan Antara Gaji Dengan Insentif}

Persamaan antara gaji dan insentif diantaranya:

1. Gaji dan insentif merupakan pendapatan (outcomes) bagi karyawan.

2. Tujuan pemberian gaji dan insentif yakni untuk memenuhi kebutuhan-kebutuhan dan ketertarikan karyawan.

3. Gaji dan insentif adalah biaya bagi perusahaan.

4. Pemberian gaji dan insentif dibenarkan oleh peraturan legal, sehingga bisa dimasukan dalam neraca fiskal perusahaan tersebut.

Sedangkan perbedaan antara gaji dan insentif

1. Gaji adalah hak karyawan untuk menerimanya dan menjadi kewajiban perusahaan untuk membayarnya, sedangkan insentif merupakan kebijakan bukan kewajiban.

2. Gaji wajib dibayar perusahaan sedangkan insentif diberikan hanya atas kebijakan saja, bukan kewajiban perusahaan jadi sewaktu-waktu dapat ditiadakan.

3. Gaji harus dibayar dengan finansial berupa uang atau barang, sedangkan insentif dapat diberikan dengan finansial dan non finansial yang dapat berupa fasilitas dan pelayanan.

4. Gaji waktu dan besarnya tertentu, sedangkan insentif waktu dan besarnya tidak tertentu.

\section{Tujuan Pemberian Insentif}


Tujuan pemberian insentif antara lain adalah untuk meningkatkan kesetiaan dan ketertarikan karyawan pada perusahaan, memberi ketenangan dan pemenuhan kebutuhan bagi karyawan beserta keluarganya, memotivasi gairah kerja, disiplin, dan produktivitas kerja karyawan, menurunkan tingkat absensi dan turnover karyawan, menciptakan lingkungan kerja yang baik serta nyaman, membantu lancarnya pelaksanaan pekerjaan untuk mencapai tujuan, memelihara kesehatan dan meningkatkan kualitas karyawan, mengefektifkan pengadaan karyawan, membantu pelaksanaan program pemerintah dalam meningkatkan kualitas manusia Indonesia, mengurangi kecelakaan, dan kesalahan kerja serta kerusakan peralatan perusahaan, dan meningkatkan status sosial karyawan beserta keluarganya.

\section{Jenis-Jenis Insentif}

Jenis-jenis insentif yang diberikan dapat berupa finansial dan non finansial yang bersifat ekonomi, pemberian fasilitas dan pelayanan. Sarwoto membedakan insentif dalam dua garis besar, yaitu: insentif material dan non material. Insentif material dapat diberikan dalam bentuk uang dan jaminan sosial. Insentif dalam bentuk uang dapat berupa bonus, komisi, profit sharing, dan kompensasi yang ditangguhkan. Sedangkan insentif non material dapat diberikan dalam berbagai bentuk, diantaranya pemberian gelar (tittle) secara resmi, tanda jasa/ medali, piagam penghargaan. Pemberian pujian lisan maupun tulisan secara resmi (didepan umum) ataupun secara pribadi, Ucapan terima kasih secara formal maupun informal, promosi berupa kenaikan pangkat atau jabatan, pemberian hak untuk menggunakan atribut jabatan, pemberian perlengkapan khusus pada ruangan kerja, pemberian hak apabila meninggal dunia dimakamkan di taman makam pahlawan, dan lain sebagainya.

\section{Metode Pemberian Insentif}

Menurut Heidjrahman dan Husnan bahwa dalam dunia industri ada beberapa sistem insentif yang biasanya digunakan dan diberikan untuk karyawan bagian produksi, yaitu:

1. Insentif berdasarkan unit yang dihasilkan (piece rate).

a. Straight Piecework Plan (upah per potong proporsional).

b. Taylor Piecework Plan (upah per potong Taylor).

c. Group Piecework Plan (upah per potong kelompok).

2. Insentif berdasarkan waktu (time bonuses).

a. Premi didasarkan atas waktu yang dihemat. Hasley Plan, 100 Persen Premium Plan, Bedaux Plan.

b. Premi didasarkan atas waktu pekerjan. Rowan Plan, Emerson Plan.

c. Premi didasarkan atas waktu standard.

Rincian jenis-jenis insentif dapat dilihat dalam tabel 1 dibawah ini: 
Tabel 1

Jenis-Jenis Insentif Karyawan ${ }^{6}$

\begin{tabular}{|c|l|l|l|}
\hline \multirow{2}{*}{ No } & \multicolumn{3}{|c|}{ Insentif } \\
\cline { 2 - 4 } & \multicolumn{1}{|c|}{ Ekonomis } & \multicolumn{1}{c|}{ Fasilitas } & \multicolumn{1}{c|}{ Pelayanan } \\
\hline 1 & Tunjangan hari khusus & Mushala/mesjid & Klinik/dokter \\
\hline 2 & Bonus tahunan & Kafetaria & Jemputan karyawan \\
\hline 3 & Uang shift & Olahraga & Asuransi/astek \\
\hline 4 & Insentif kehadiran & Kesenian & Bantuan hukum \\
\hline 5 & Tunjangan keluarga & Pendidikan/seminar & Penasehat keuangan \\
\hline 6 & Uang fisik & Cuti dan cuti hamil & Kredit rumah \\
\hline 7 & Tunjangan jabatan & Koperasi dan toko & \\
\hline 8 & Tunjangan perumahan & & \\
\hline
\end{tabular}

\section{Faktor-Faktor Yang Mempengaruhi Insentif}

\section{Pengaruh Internal}

a. Anggaran tenaga kerja

Anggaran tenaga kerja secara normal identik dengan jumlah uang yang tersedia. Setiap perusahaan dalam menetapkan insentif dipengaruhi oleh usulan anggaran tenaga kerja tersebut.

b. Siapa yang membuat keputusan

Pemimpin yang otoriter akan berbeda dengan pemimpin yang partisipatif dalam membuat keputusan; atas berapa banyak yang harus dibayar, sistem apa yang dipakai, manfaat apa yang ditawarkan, dan sebagainya. Perusahaan besar kini lebih menyertakan individu dalam menentukan besarnya insentif. Paksaan dari persainganinternasional sudah mengubah pendekatan perusahaan tersebut.

\section{Pengaruh Eksternal}

a. Pasar tenaga kerja

Pasar tenaga kerja mempengaruhi desain insentif dalam dua cara. Pertama, tingkat persaingan tenaga kerja sebagian menentukan batas rendah atau floor tingkat pembayaran. Jika tingkat pembayaran suatu perusahaan terlalu rendah, tenaga kerja yang memenuhi syarat tidak akan bersedia diperusahaan itu. Permintaan mendorong harga tenaga kerja naik, akan tetapi harga tinggi pada gilirannya menarik lebih banyak orang masuk ke pasar tenaga kerja. Kedua, tenaga kerja menekan perusahaan untuk mencari alternatif, seperti penyediaan tenaga kerja kontrak, tenaga kerja asing, yang mungkin harganya lebih rendah, atau teknologi yang dapat mengurangi kebutuhan akan tenaga kerja. 


\section{b. Kondisi ekonomi}

Kondisi ekonomi industri, terutama derajat tingkat persaingan, yang mempengaruhi kesanggupan perusahaan untuk membayar. Semakin kompetitif situasinya, maka semakin rendah kemampuan perusahaan untuk membayar. Kesanggupan untuk membayar adalah juga suatu konsekuensi produktifitas yang relatif dalam perusahaan, industri, atau sektor lain. Produktifitas bisa meningkat dengan majunya teknologi, lebih efisiennya metode operasi, kerja yang lebih keras dan lebih besarnya dorongan kerja, atau suatu kombinasi dari faktor-faktor tersebut.

c. Peraturan pemerintah

Pemerintah secara langsung mempengaruhi tingkat kesejahteraan melalui pengendalian upah dan hukum yang menetapkan tingkat tarif upah minimum regional, gaji, pengaturan jam kerja, dan mencegah diskriminasi.

d. Serikat pekerja

Kehadiran serikat pekerja di perusahaan sektor swasta diperkirakan meningkatkan upah 10 sampai $20 \%$ dan menaikan tunjangan sekitar 20 sampai $30 \%{ }^{7}$

\section{Kinerja}

\section{Pengertian Kinerja}

Menurut Mangkunegara, istilah kinerja berasal dari kata Performance, Job Performance atau Actual Performance sering diartikan sebagai kinerja, hasil kerja, prestasi kerja atau prestasi sesungguhnya yang dicapai seseorang. Dalam hal ini, Mangkunegara mengemukakan bahwa "Pengertian kinerja atau prestasi kerja adalah hasil kerja secara kualitas dan kuantitas yang dicapai oleh seorang pegawai dalam melaksanakan tugasnya sesuia dengan tanggung jawab yang diberikan kepadanya". ${ }^{8}$

Malayu S.P. Hasibuan mengungkapkan pendapatnya tentang prestasi kerja yaitu hasil yang dicapai seseorang dalam melaksanakan tugas-tugas yang dibebankan yang didasarkan atas kecakapan, pengalaman dan kesungguhan serta waktu. Prestasi kerja merupakan gabungan dari tiga faktor penting, yaitu kemampuan dan minat seorang pekerja, kemampuan dan penerimaan atas penjelasan delegasi tugas, serta peran dan tingkat motivasi seorang pekerja. Semakin tingggi ketiga faktor diatas, semakin besarlah pretasi kerja karyawan yang bersangkutan. ${ }^{9}$

Selanjutnya Wibowo berpendapat: "Kinerja dapat dipandang sebagai proses maupun hasil pekerjaan. Kinerja merupakan suatu proses tentang bagaimana pekerjaan berlansung untuk mencapai hasil kerja. Namun hasil kerja sendiri menunjukan kinerja". ${ }^{10}$

Armstrong dan Baron menyatakan bahwa kinerja mempunyai makna yang lebih luas, bukan hanya menyatakan hasil kerja, tetapi juga bagaimana proses kerja berlangsung, kinerja adalah tentang melakukan pekerjaan dan hasil yang dicapai dari pekerjaan tersebut. Kinerja adalah tentang apa yang dikerjakan dan bagaimana cara mengerjakannya. Kinerja merupakan hasil pekerjaan yang mempunyai hubungan kuat 
dengan tujuan strategis organisasi, kepuasan konsumen dan memberikan kontribusi ekonomi. ${ }^{11}$

Kinerja karyawan lebih mengarah pada tingkatan prestasi kerja karyawan. Kinerja karyawan merefleksikan bagaimana karyawan memenuhi keperluan pekerjaan dengan baik.

Hadari Nawawi mengemukakan "Kinerja diartikan sebagai tingkat efektivitas dan efisiensi pelaksanaan pekerjaan (Performance) yang menghasilkan prestasi kerja, yang dikategorikan produktif dari segi jumlah (kuantitas) dan nilai internal berupa kualitas, proses dalam menghasilkan sesuatu dan nilai eksternal berupa kualitas hasilnya." 12

Karyawan memiliki kinerja yang baik apabila yang bersangkutan memahami akan fungsi dan tugasnya dengan baik. Oleh karena itu seorang karyawan harus memiliki bekal atau pengetahuan yang luas tentang pekerjaannya sehingga tahu betul tentang tugas yang mesti dilakukannya. Dari aspek personal diperlukan adanya tanggung jawab dan kesadaran yang mendalam untuk menciptakan suatu kinerja yang baik, sebab dapat dikatakan bahwa kinerja yang baik berkaitan dengan kesadaran karyawan terhadap pekerjaan mereka.

\section{Tujuan dan Sasaran Kinerja}

Kinerja bertujuan untuk menyesuaikan harapan kinerja individu dengan tujuan organisasi. Kesesuaian antara upaya pencapaian tujuan individu dengan tujuan organisasi akan mampu mewujudkan kinerja yang baik. Tujuan mengalir dari atas ke bawah, sedangkan tanggung jawab bergerak dari bawah ke atas. Oleh karena itu tujuan dari atas memberikan inspirasi untuk menetapkan tujuan dibawahnya, sementara itu tanggung jawab dilakukan secara berjenjang dari bawah keatas sesuai dengan tugas dan kewenangan masing-masing tingkatan.

Sedangkan sasaran kinerja merupakan suatu pernyataan secara spesifik yang menjelaskan hasil yang harus dicapai, kapan, dan oleh siapa sasaran yang diinginkan dicapai tersebut diselesaikan. Sifatnya dapat dihitung, prestasi yang dapat diamati, dan dapat diukur. Dengan kata lain sasaran merupakan harapan yang mencakup unsur-unsur diantaranya;

1) The performers, yaitu orang yang menjalankan kinerja.

2) The action atau performance, yaitu tentang tindakan atau kinerja yang dilakukan oleh performer.

3) A time element, menunjukan waktu kapan pekerjaan dilakukan.

4) An evaluation method, tentang cara penilaian bagaimana hasil pekerjaan dapat dicapai.

5) The place, menunjukan tempat dimana pekerjaan dilakukan.

Sasaran yang efektif dinyatakan secara spesifik, dapat diukur, dapat dicapai, berorientasi pada hasil, dan dalam batasan waktu tertentu, yang dapat dinyatakan dengan akronim SMART yang berarti sebagai berikut: 
(S) - Specific: artinya dinyatakan jelas, singkat dan mudah dimengerti.

(M) - Measurable: artinya dapat diukur dan di kuantikasi.

(A) - Attainable: artinya bersifat menantang, tetapi masih dapat terjangkau.

(R) - Result oriented: artinya fokus pada hasil untuk dicapai.

(T) -Time-bond: artinya ada batas waktu dan dapat dilacak, dapat dimonitor progresnya terhadap sasaran untuk dikoreksi.

Hasil kinerja dapat dinyatakan sebagai meningkatkan produksi, menurunkan biaya operasi, dan meningkatkan penjualan per tahun dan seterusnya.

Faktor-Faktor Yang Mempengaruhi Kinerja

Ada beberapa faktor yang mempengaruhi kinerja diantaranya faktor kemampuan (ability) dan faktor motivasi (motivation). Hal ini sesuai dengan pendapat Keith Davis yang merumuskan bahwa:
i. Human Performance= Ability + Motivation
ii. Motivation = Attitude + Situation
iii. Ability
= Knowledge + Skill

\section{a. Faktor Kemampuan}

Secara psikologis, kemampuan (ability) karyawan terdiri dari kemampuan potensi (IQ) dan kemampuan reality (knowledge + skill). Artinya, karyawan yang memiliki IQ di atas rata-rata (IQ 110-120) dengan pendidikan yang memadai untuk jabatannya dan terampil dalam mengerjakan pekerjaan sehari-hari, maka ia akan lebih mudah mencapai kinerja yang diharapkan. Oleh karena itu, karyawan perlu ditempatkan pada pekerjaan yang sesuai dengan keahliannya.

\section{b. Faktor Motivasi}

Motivasi terbentuk dari sikap (attitude) seorang karyawan dalam menghadapi situasi (situation) kerja. Motivasi merupakan kondisi yang menggerakan diri karyawan yang terarah untuk mencapai tujuan organisasi (tujuan kerja). Sikap mental merupakan kondisi mental yang mendorong diri karyawan untuk berusaha mencapai prestasi kerja secara maksimal.

Sikap mental karyawan harus sikap mental yang siap secara psikofisik (siap secara mental, fisik, tujuan, dan situasi). Artinya, seorang karyawan harus siap mental, mampu secara fisik, memahami tujuan utama dan target kerja yang akan dicapai, mampu memanfaatkan, dan menciptakan situasi kerja. Kesemuanya itubisa tercapai apabila karyawan memiliki "Modal" (mengolah, otak, dengan, aktif dan incah) dan "Kreatif" (keinginan maju, rasa ingin tahu tinggi, energik, analisis sistematik, terbuka dari kekurangan, inisiatif tinggi, dan pikiran luas).

Menurut pendapat Armstrong dan Baron faktor yang mempengaruhi kinerja yaitu sebagai berikut: 
1) Personal factor, ditunjukan oleh tingkat keterampilan, kompetensi yang dimiliki, motivasi dan komitmen individu.

2) Leadership factor, ditentukan oleh kualitas dorongan, bimbingan, dan dukungan yang dilakukan manajer dan team leader.

3) Team factor, ditunjukan oleh kualitas dukungan yang diberikan oleh rekan sekerja.

4) System factor, ditunjukan oleh adanya sistem kerja dan fasilitas yang diberikan organisasi.

5) Contextual/situational factor, ditunjukan oleh tingginya tingkat tekanan dan perubahan lingkungan internal dan eksternal. ${ }^{13}$

Sementara itu, menurut Hersey, Blanchard dan Johnson merumuskan adanya tujuh faktor yang mempengaruhi kinerja dan dituliskan dengan akronim ACHIEVE:

A - Ability (Knowledge dan skill)

C - Clarity (understanding atau role perception)

$\mathbf{H}$ - Help (organization support)

I - Incentive (motivation atau willingness)

E - Evaluation (coaching dan performance feedback)

$\mathbf{V}$ - Valid (valid dan legal personal practices)

E - Environment (environmental fit) ${ }^{14}$

\section{Penilaian Prestasi Kerja}

Penilaian prestasi pegawai dikenal dengan istilah "konduite, performance rating, performance apprasial, personnel assesment, personnel review, employee evaluation, merit rating, efeciency rating, service rating, dan atau behavioral assessment ". ${ }^{15}$

Leon C. Magginson mengemukakan bahwa "performance appraisal is the process an employer uses to determine whether an employee performing the job as intented" berdasarkan pendapat Leon C. Magginson bahwa "Performance appraisal adalah suatu proses yang digunakan majikan untuk menentukan apakah seorang pegawai melakukan pekerjaanya sesuai dengan yang dimaksudkan". ${ }^{16}$

Andrew E, Sikula menjelaskan bahwa "Employee appraisng is the systematic evaluation of a workers job performance and potential for development. Appraising is the proses of estimating or jugging the value, exellence, qualities, or status of some object, person, or thing". Berdasarkan pendapat Andrew E. Sikula bahwa "penilaian pegawai merupakan evaluasi yang sistematik dari pekerjaan pegawai dan potensi yang dapat dikembangkan. Penilaian adalah proses penaksiran atau penentuan nilai, kualitas, atau status dari beberapa objek, orang ataupun sesuatu". ${ }^{17}$

\section{Tujuan Penilaian Prestasi Kerja}

Tujuan penilaian prestasi kerja antara lain:

1) Sebagai dasar dalam pengambilan keputusan yang digunakan untuk promosi, demosi, pemberhentian, dan penetapan besarnya balas jasa. 
2) Untuk mengukur pretasi kerja yaitu sejauh mana karyawan bisa sukses dalam pekerjaannya.

3) Sebagai dasar untuk mengevaluasi efektivitas seluruh kegiatan di dalam perusahaan.

4) Sebagai dasar evaluasi program latihan dan keefektifan jadwal kerja, metode kerja, struktur organisasi, gaya pengawasan, kondisi kerja, danperalatan kerja.

5) Sebagai indikator untuk menetukan kebutuhan akan latihan bagi karyawan yang berada dalam organisasi.

6) Sebagai alat untuk meningkatkan motivasi kerja karyawan sehingga dicapai tujuan untuk mendapatkan performance kerja yang baik.

7) Sebagai alat untuk mendorong atau membiasakan para atasan (supervisor, managers, administrator) untuk untuk mengobservasi perilaku bawahan (subordinate) supaya diketahui minat dan kebutuhan-kebutuhan bawahannya.

8) Sebagai alat untuk bisa melihat kekurangan atau kelemahan-kelemahan di masa lampau dan meningkatkan kemampuan karyawan selanjutnya.

9) Sebagai kriteria dalam menentukan seleksi dan penempatan karyawan.

10) Sebagai alat untuk mengidentifikasi kelemahan-kelemahan personil dan dengan demikian bisa sebagai bahan pertimbangan agar bisa di ikut sertakan dalam program latihan kerja tambahan.

11) Sebagai alat untuk memperbaiki atau mengembangkan kecakapan karyawan.

12) Sebagai dasar untuk memperbaiki dan mengembangkan uraian pekerjaan (job description).

\section{Faktor-Faktor Yang Dinilai}

Secara umum faktor-faktor yang dinilai dalam sistem penilaian prestasi kerja yang berlaku dalam suatu perusahaan yaitu: kesetiaan, prestasi kerja, kejujuran, kedisiplinan, kreatif, kerjasama, kepemimpinan, kepribadian, prakarsa, kecakapan, dan tanggungjawab.

\section{Perangkap Dalam Penilaian Kinerja}

Dalam melakukan penilaian terhadap pekerja, harus dihindari adanya jebakan atau bias yang dapat ditimbulkan karena adanya The halo effect maupun The horn effect.

\section{1) The Halo Effect}

The halo effect menunjukan suatu kecenderungan penilai untuk menilai lebih tinggi orang yang menjadi favorit. Hal ini terjadi karena beberapa alasan berikut ini.

a) Effect of past record

Mengasumsikan karyawan yang telah melakukan pekerjaan baik di masa yang lalu, kinerjanya baik pula pada masa sekarang.

b) Compatibility 
Comtability merupakan kecenderungan menilai karyawan yang mempunyai kebiasaan dan kepribadian yang lebih memuaskan dibandingkan dengan mereka yang berhak. Karyawan yang setuju dengan pimpinan, yang mengangguk-anggukan kepala ketika pimpinan bicara, atau siapa yang membuat catatan tentang kata-kata pimpinan, karyawan ini mendapat penilaian lebih besar daripada kinerja mereka sebenarnya.

c) Effect of recency

Pekerjaan luar biasa yang dilakukan minggu yang lalu atau kemarin dapat mencakup makna kinerja sepanjang sisa tahun.

d) The one-assets person

Pembicara yang fasih, orang dengan penampilan impresif, atau titel yang tinggi atau lulusan almamater penilai, mendapat penilaian lebih menyenangkan daripada karyawan yang kekurangan atribut ini.

e) The blind-spot effect

Merupakan kasus dimana penilai tidak melihat tipe cacat atau kesalahan tertentu karena mereka seperti miliknya sendiri. Misalnya, penilai yang menyukai akunting mungkin menilai lebih detail orang ini.

\section{f) The high-potential effect}

Penilai kadang-kadang lebih mempertimbangkan kertas catatan karyawan dari pada apa yang telah mereka selesaikan untuk organisasi.

\section{g) The no-complain bias}

Penilai memperlakukan bahwa tidak ada berita sebagai berita baik. Pekerja yang tidak mempunyai keberatan dan menyatakan bahwa semua hal berjalan baik mungkin perlu memeriksa dengan lebih baik.

\section{2) The Horn Effect}

The horn effect merupakan merupakan kebalikan dari The halo effect, yaitu merupakan kecenderungan untuk menilai karyawan lebih rendah dari keadaan sebenarnya. Beberapa penyebab terjadinya The horn effect adalah sebagai berikut.

\section{a) The manager is perfectionist}

Penilai berkeinginan agar bawahan seperti dirinya. Karena harapannya terlalu tinggi, ia sering kecewa dan menilai pekerja lebih rendah dari pada seharusnya.

b) The Employee is contrary

Penilai secara pribadi jengkel dengan kecenderungan pekerja untuk terlalu sering tidak menyetujui atas terlalu banyak masalah.

\section{c) The oddball effect}

Semua keramahan untuk menyenangkan saja jarang dihitung ketika waktu penilaian datang. Karyawan yang bersifat lain daripada lainnya mendapat penilaian rendah hanya karena mereka berbeda. 


\section{d) Membership in a weak team}

Karyawan baik pada tim atau section yang lemah berakhir dengan penilaian lebih rendah daripada apa yang akan mereka dapatkan apabila ia berada pada winning team.

e) The guilt-by-association effect

Karyawan yang tidak benar-benar dikenal oleh manajer sering kurang mendapat perlindungan/keringanan dari sebuah hukuman perusahaan dibandingkan dengan karyawan yang dikenal lebih baik.

\section{f) The dramatic-incident effect}

Perbuatan bodoh yang baru dilakukan dapat menghapus pengaruh kerja baik berbulan-bulan dan memberikan penilaian lebih rendah pada karyawan daripada seharusnya.

\section{g) The personality-trait effect}

Pekerja yang terlalu yakin, terlalu tidak tahu malu, terlalu lembut hati atau terlalu pasif yang kekurangan beberapa sifat penilai yang berkaitan dengan pekerja baik, menderita dalam penilaian.

\section{h) The self-comparison effect}

Karyawan yang melakukan pekerjaan secara berbeda dari cara yang dilakukan penilai ketika ia mempunyai pekerjaan tersebut akan lebih menderita daripada karyawan yang mempunyai pekerjaan yang tidak pernah dilakukan penilai. ${ }^{18}$

\section{Kerangka Pemikiran}

Insentif yang baik, akan membantu perusahaan dalam mencapai tujuan, dan memperoleh, memelihara, dan menjaga karyawan dengan baik, sebaliknya tanpa insentif yang cukup, karyawan yang ada sangat mungkin untuk meninggalkan perusahaan dan untuk melakukan penempatan kembali tidaklah mudah.

Untuk dapat memberikan kinerja yang baik, karyawan perlu diberikan insentif yang baik pula. Insentif yang diberikan sangat berarti dan bermanfaat untuk memenuhi kebutuhan fisik dan mental karyawan beserta keluarganya, yang semakin lama semakin bertambah. Pemberian insentif akan menciptakan ketenangan, semangat kerja, dedikasi, disiplin, dan sikap loyal karyawan terhadap perusahaan sehingga labour turnover relatif rendah.

Kinerja karyawan dapat dipengaruhi oleh bermacam-macam ciri pribadi dari masing-masing individu dan lingkungan perusahaan. Perusahaan membutuhkan karyawan yang memiliki kinerja tinggi, dan pada saat yang sama untuk memenuhi segala kebutuhannya, karyawan memerlukan umpan balik berupa insentif atas kinerja yang mereka berikan.

Berdasarkan uraian tersebut maka penulis beranggapan bahwa dengan program insentif yang baik dan benar, akan mampu meningkatkan kinerjakaryawan. Untuk lebih jelasnya mengenai kerangka pemikiran pengaruh 
pemberian insentif terhadap kinerja karyawan, maka dapat dijelaskan seperti gambar berikut.

\section{Gambar 1.}

Kerangka Pemikiran

\begin{tabular}{|ll|}
\hline \multicolumn{1}{|c|}{ Insentif $(\mathbf{X})$ : } \\
1. & Tunjangan hari khusus \\
2. & Bonus tahunan \\
3. & Uang suka dan duka \\
4. & Insentif kehadiran \\
5. & Tunjangan fisik \\
6. & Tunjangan jabatan \\
7. & Fasilitas \\
8. & Pelayanan \\
\hline
\end{tabular}

\begin{tabular}{|ll|}
\hline \multicolumn{1}{|c|}{ Kinerja (Y) } \\
1. & Pemahaman tugas \\
2. & Hasil kerja \\
3. & Motivasi \\
4. & disiplin kerja \\
5. & Kreativitas/inovasi \\
6. & Kerjasama \\
\hline
\end{tabular}

\section{Hipotesis}

Hipotesis merupakan jawaban sementara terhadap rumusan masalah penelitian, yang berfungsi sebagai petunjuk ke arah pemecahan masalah. Hipotesis sangat diperlukan dalam penelitian supaya dapat memudahkan jalannya penelitian. Hipotesis dari penelitian ini adalah diduga ada pengaruh positif dan signifikan antara pemberian insentif terhadap kinerja karyawan.

\section{Metodologi Penelitian}

\section{Definisi Operasional Variabel}

Dalam penelitian yang berjudul pengaruh insentif terhadap kinerja karyawan terdapat dua variabel yaitu, variabel insentif $(\mathrm{X})$ terdiri dari 8 indikator dan variabel kinerja (Y) terdiri dari 6 indikator. Indikator penelitian tersebut, dapat dilihat dalam tabel 2 di bawah ini:

Tabel 2

Kisi-Kisi Instrumen Untuk Mengukur Insentif dan Kinerja Karyawan

\begin{tabular}{|c|c|c|}
\hline $\begin{array}{l}\text { Variabel } \\
\text { Penelitian }\end{array}$ & Indikator & $\begin{array}{c}\text { No. item } \\
\text { pertanyaan }\end{array}$ \\
\hline \multirow{6}{*}{ Insentif (X) } & 1. Jaminan hari khusus & 1 \\
\hline & 2. Bonus & 2 \\
\hline & 3. Uang suka cita dan duka cita & 3 \\
\hline & 4. Insentif kehadiran & 4 \\
\hline & 5. Tunjangan fisik & 5 \\
\hline & 6. Insentif Jabatan & 6 \\
\hline
\end{tabular}




\begin{tabular}{|l|l|l|}
\hline \multicolumn{1}{|c|}{$\begin{array}{c}\text { Variabel } \\
\text { Penelitian }\end{array}$} & \multicolumn{1}{|c|}{ Indikator } & \multicolumn{1}{|c|}{$\begin{array}{c}\text { No. item } \\
\text { pertanyaan }\end{array}$} \\
\hline \multirow{5}{*}{ Kinerja (Y) } & 7. Fasilitas & $7,8,9$ \\
\cline { 2 - 3 } & 8. Pelayanan & $10,11,12$ \\
\hline & 1. Pemahaman tugas & 1,2 \\
\cline { 2 - 3 } & 2. Hasil kerja & 3,4 \\
\cline { 2 - 3 } & 3. Motivasi & 5,6 \\
\cline { 2 - 3 } & 4. Disiplin & 7,8 \\
\cline { 2 - 3 } & 5. Kreativitas/inovasi & 9 \\
\cline { 2 - 3 } & 6. Kerjasama & $10,11,12$ \\
\hline
\end{tabular}

\section{Metode Penelitian}

Metode penelitian yang digunakan adalah penelitian survey dengan tingkat explanasi penelitian asosiatif dengan tujuan untuk mengetahui hubungan antara kedua variabel. Selanjutnya untuk mengukur variabel dari sebuah penelitian digunakan skala Likert. Dalam menyebarkan kuesioner, setiap item intrumen mempunyai gradasi jawaban dari sangat positif sampai sangat negatif, dengan alternatif jawaban sebagai berikut: Sangat Baik (SB) diberi skor5; Baik (B) diberi skor 4; Cukup Baik (CB) diberi skor 3; Tidak Baik (TB) diberi skor 2; Sangat Tidak Baik (STB) diberi skor 1.

\section{Populasi dan Sampel}

Dalam penelitian ini, yang menjadi populasi penelitian adalah karyawan berjumlah 58 orang, sedangkan sampel dalam penelitian sebanyak 54 orang ditentukan berdasarkan tabel penentuan jumlah sampel dari populasi tertentu yang dikembangkan oleh Isaac dan Michael. ${ }^{19}$

\section{Jenis Data}

Dalam penelitian ini, data yang digunakan adalah data primer dan data sekunder. Data primer merupakan data yang didapat langsung dari sumber pertama baik dari individu atau perseorangan seperti hasil wawancara atau hasil kuesioner yang dilakukan oleh peneliti. Data sekunder merupakan data primer yang telah diolah lebih lanjut dan disajikan baik oleh pihak pengumpul atau oleh pihak lain.

\section{Teknik Analisis Data}

Setelah data terkumpul dari seluruh responden, langkah selanjutnya melakukan analisis data dengan melakukan perhitungan untuk menguji hipotesis yang terdiri 
dari:Uji Validitas, Uji Reliabilitas, Uji Korelasi Product Moment, Uji Koefisien Determinasi, Uji Signifikansi, Uji Regresi Linear Sederhana, dan Hipotesis Statistik.

Pengujian hipotesis yang dilakukan yaitu terhadap hipotesis nol $\left(\mathrm{H}_{0}\right)$ dengan satu hipotesis alternatif (Ha). Untuk itu sebelumnya dicari korelasi antara variabel $\mathrm{X}$ dengan variabel Y, dengan rumus yang digunakan adalah korelasi Product Moment. yang selanjutnya hasil perhitungan tersebut $\mathrm{r}_{\text {hitung }}$ dibandingkan dengan $\mathrm{r}_{\text {tabel. }}$

$\mathrm{H}_{0}$ : Tidak terdapat pengaruh yang positif antara insentif terhadap kinerja karyawan.

Ha: Terdapat pengaruh yang positif antara insentif terhadap kinerja karyawan.

\section{Hasil Dan Pembahasan}

\section{Uji Prasyarat Analisa}

\section{Uji Prasyarat Analisa Insentif (X)}

Data yangdiperoleh dari penyebaran kuesioner dengan hasil sebagai berikut: Jumlah skor kriterium yaitu bila setiap item mendapat skor tertinggi $=5 \times 12 \times 54=$ 3.240 (skor tertinggi tiap item pertanyaan $=5$, jumlah item $=12$ dan jumlah responden $=54$ ). Berdasarkan hasil pengumpulan data jumlah skor total $=2.544$. Dengan demikian tingkat penilaian terhadap insentif karyawan menurut pendapat 54 responden yaitu $2.544: 3.240=0,785(78,5 \%)$ dari kriteria yang ditetapkan, hal ini secara kontinum dapat digambarkan sebagai berikut:

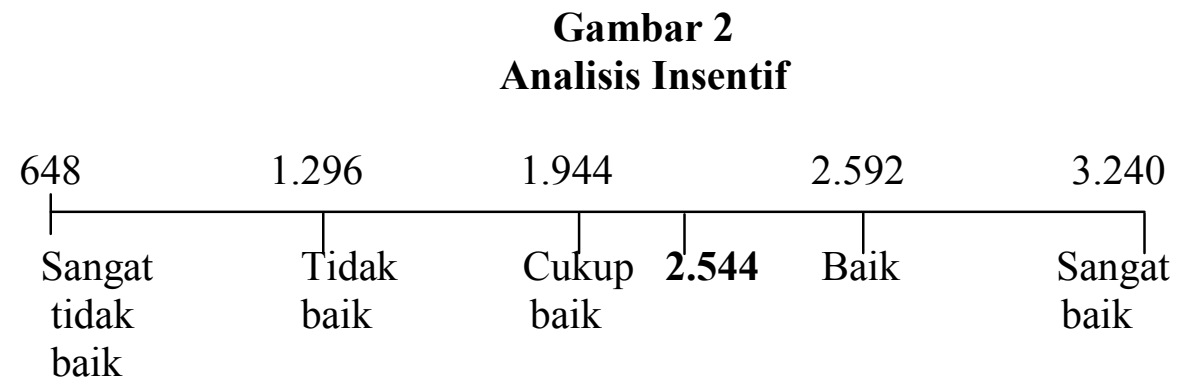

Nilai 2.544 termasuk dalam katagori interval antara"cukup baik dan baik" tetapi lebih mendekati cukup baik. Jadi kesimpulannya secara keseluruhan insentif karyawan termasuk dalam katagori cukup baik.

\section{Uji Prasyarat Analisa Kinerja Karyawan (Y)}

Data yangdiperoleh dari penyebaran kuesioner adalah jumlah skor kriterium yaitu bila setiap item mendapat skor tertinggi $=5 \times 12 \times 54=3.240$ (skor tertinggi tiap item pertanyaan $=5$, jumlah item $=12$ dan jumlah responden $=54$ ), berdasarkan hasil pengumpulan data jumlah skor total $=2.646$. Dengan demikian tingkat penilaian terhadap kinerja karyawan menurut pendapat 54 responden yaitu 2.646 : 
$3.240=0,817(81,7 \%)$. Dari kriteria yang ditetapkan, hal ini secara kontinum dapat digambarkan sebagai berikut:

\section{Gambar 3 \\ Analisis Kinerja}

\begin{tabular}{llll|lc|}
648 & 1.296 & 1.944 & \multicolumn{2}{c}{2.592} & 3.240 \\
$\begin{array}{l}\text { Sangat } \\
\text { tidak } \\
\text { baik }\end{array}$ & $\begin{array}{l}\text { Tidak } \\
\text { baik }\end{array}$ & $\begin{array}{l}\text { Cukup } \\
\text { baik }\end{array}$ & Baik 2.646 & $\begin{array}{c}\text { Sangat } \\
\text { baik }\end{array}$
\end{tabular}

Nilai 2.646 termasuk dalam katagori interval "cukup baik dan baik" tetapi lebih mendekati baik. Jadi kesimpulannya kinerja karyawan termasuk dalam katagori baik.

\section{Pengujian Hipotesis \\ Uji Validitas}

Pengujian vailiditas instrumen penelitian dilakukan berdasarkan data hasil penyebaran kuesioner, yang masing-masing variabel terdiri dari 12 item pertanyaan dengan jumlah responden sebanyak 54 orang. Perhitungan validitas instrumen menggunakan rumus sebagai berikut:

$$
r_{x y}=\frac{n \sum \text { xiyi }-\left(\sum \text { xi }\right)\left(\sum y i\right)}{\sqrt{\left\{n \sum \mathrm{xi}^{2}-\left(\sum x i\right)^{2}\right\}\left\{n \sum \mathrm{yi}^{2}-\left(\sum y i\right)^{2}\right\}}}
$$

\section{Uji Validitas Instrumen Insentif (X)}

Berdasarkan atas data yang diperoleh, validitas instrumen insentif item pertanyaan nomor 1 , diketahui hasil perhitungannya sebagai berikut: $\mathrm{n}=54$; $\sum \mathrm{xi}=$ $221 ; \sum \mathrm{xi}^{2}=921 ; \sum \mathrm{yi}=2544 ; \sum \mathrm{yi}^{2}=120660 ; \sum \mathrm{xiyi}=10466$, dengan menggunakan rumus : di atas diperoleh $\mathrm{r}_{\mathrm{xy}}=0,471$.

Selanjutnya validitas instrumen insentif item pertanyaan nomor $2 \sim 12$, dihitung dengan menggunakan rumus dan cara perhitungan sama seperti pada perhitungan item nomor 1 di atas, maka diperoleh hasil sebagai mana tercantum dalam tabel 3 dibawah ini. 
Tabel 3

Hasil Analisis Validitas Item Instrumen Insentif

\begin{tabular}{|c|c|c|c|}
\hline $\begin{array}{c}\text { Nomor Butir } \\
\text { Instrumen }\end{array}$ & $\begin{array}{c}\text { Koefisien } \\
\text { Korelasi }\end{array}$ & $\begin{array}{c}\text { Syarat } \\
\text { Minimum }\end{array}$ & Keterangan \\
\hline 1 & 0.471 & 0.348 & Valid \\
\hline 2 & 0.563 & 0.348 & Valid \\
\hline 3 & 0.410 & 0.348 & Valid \\
\hline 4 & 0.418 & 0.348 & Valid \\
\hline 5 & 0.459 & 0.348 & Valid \\
\hline 6 & 0.443 & 0.348 & Valid \\
\hline 7 & 0.470 & 0.348 & Valid \\
\hline 8 & 0.522 & 0.348 & Valid \\
\hline 9 & 0.494 & 0.348 & Valid \\
\hline 10 & 0.461 & 0.348 & Valid \\
\hline 11 & 0.427 & 0.348 & Valid \\
\hline 12 & 0.468 & 0.348 & Valid \\
\hline
\end{tabular}

Berdasarkan data di atas, semua koefisien korelasi memiliki nilai lebih besar dari syarat minimal $r_{\text {tabel }}=0,348$, maka semua item instrumen untuk variabel insentif dari nomor $1-12$ dinyatakan valid.

\section{Uji Validitas Instrumen Kinerja (Y)}

Berdasarkan atas data yang diperoleh, validitas instrumen kinerja item pertanyaan nomor 1 , diketahui hasil perhitungan datanya sebagai berikut: $\mathrm{n}=54 ; \sum \mathrm{xi}$ $=240 ; \sum \mathrm{xi}^{2}=1086 ; \sum \mathrm{yi}=2646 ; \sum \mathrm{yi}^{2}=130176 ; \sum \mathrm{xiyi}=11811$. Dengan menggunakan rumus validitas instrumen di atas diperoleh $\mathrm{r}_{\mathrm{xy}}=0,508$.

Selanjutnya validitas instrumen kinerja item pertanyaan nomor $2 \sim 12$, dihitung dengan menggunakan rumus dan cara perhitungan yang sama seperti pada perhitungan item nomor 1 di atas, maka diperoleh hasil sebagai mana tercantum dalam tabel 4 dibawah ini:

\section{Tabel 4}

Hasil Analisis Validitas Item Instrumen Kinerja

\begin{tabular}{|c|c|c|c|}
\hline $\begin{array}{c}\text { Nomor Butir } \\
\text { Instrumen }\end{array}$ & $\begin{array}{c}\text { Koefisien } \\
\text { Korelasi }\end{array}$ & $\begin{array}{c}\text { Syarat } \\
\text { Minimum }\end{array}$ & Keterangan \\
\hline 1 & 0.508 & 0.348 & Valid \\
\hline 2 & 0.527 & 0.348 & Valid \\
\hline
\end{tabular}




\begin{tabular}{|c|c|c|c|}
\cline { 2 - 2 } 3 & 0.427 & 0.348 & Valid \\
\hline 4 & 0.482 & 0.348 & Valid \\
\hline 5 & 0.503 & 0.348 & Valid \\
\hline 6 & 0.534 & 0.348 & Valid \\
\hline 7 & 0.489 & 0.348 & Valid \\
\hline 8 & 0.501 & 0.348 & Valid \\
\hline 9 & 0.506 & 0.348 & Valid \\
\hline 10 & 0.401 & 0.348 & Valid \\
\hline 11 & 0.440 & 0.348 & Valid \\
\hline 12 & 0.464 & 0.348 & Valid \\
\hline
\end{tabular}

Berdasarkan data tersebut, semua koefisien korelasi memiliki nilai lebih besar dari syarat minimal $r_{\text {tabel }}=0,348$, maka semua item instrumen untuk variabel kinerja dari nomor $1-12$ dinyatakan valid.

\section{Uji Reliabilitas}

Hasil dari uji ini sebagai $r_{\text {hitung }}$ akan dibandingkan dengan $r_{\text {tabel }}$ product moment, untuk menentukan reliabel atau tidak sebuah variabel.

\section{Uji Reliabilitas Instrumen Insentif (X)}

Pengujian reliabilitas dapat diketahui hasil perhitungan datanya berikut ini: $\mathrm{n}$ $=54 ; \sum x i=1285 ; \sum \mathrm{xi}^{2}=30803 ; \sum \mathrm{yi}=1259 ; \sum \mathrm{yi}^{2}=29667 ; \sum \mathrm{xiyi}=30095$. Dengan menggunakan rumus yang sama dengan uji validitas di atas, diperoleh $\mathrm{r}_{\mathrm{xy}}=0.51$. berikut:

Reliabilitas instrumen insentif selanjutnya dihitung menggunakan rumus

$$
\frac{r_{i}=\frac{2 r_{x y}}{1+r_{x y}}}{r_{i}=0.676}
$$

Hasil $\mathrm{r}_{\text {hitung }}=0,676$. Tabel nilai-nilai $\mathrm{r}$ product moment, dengan $\mathrm{n}=54$, dan taraf kesalahan $1 \%$, maka diperoleh $\mathrm{r}_{\text {tabel }}=0,348$. hal ini berarti $\mathrm{r}_{\text {hitung }}$ lebih besar dari $\mathrm{r}_{\text {tabel }}(0.676>0,348)$, maka instrumen insentif dinyatakan reliabel.

\section{Uji Reliabilitas Instrumen Kinerja Karyawan (Y)}


Pengujian reliabilitas diketahui hasil perhitungan datanya sebagai berikut, $\mathrm{n}=$ 54; $\sum \mathrm{xi}=1343 ; \sum \mathrm{xi}^{2}=33553 ; \sum \mathrm{yi}=1303 ; \sum \mathrm{yi}^{2}=31617 ; \sum \mathrm{xiyi}=32503$. Dengan menggunakan rumus uji validitas diperoleh $\mathrm{r}_{\mathrm{xy}}=0,592$.

Reliabilitas instrumen kinerja selanjutnya dihitung menggunakan rumus yang sama di atas, maka diperoleh $\mathrm{r}_{\mathrm{i}}=0,744$.

Hasil $\mathrm{r}_{\text {hitung }}=0,744$. Berdasarkan nilai $\mathrm{r}$ product moment, dengan $\mathrm{n}=54$, dan taraf kesalahan $1 \%$, maka diperoleh $\mathrm{r}_{\text {tabel }}=0,348$. Hal ini berarti $\mathrm{r}_{\text {hitung }}$ lebih besar dari $\mathrm{r}_{\text {tabel }}(0,744>0,348)$. Dengan demikian maka instrumen kinerja dinyatakan reliabel.

\section{Uji Koefisien Korelasi Produk Moment}

Hasil perhitungan korelasi product moment dapat di lihat sebagai berikut, $\mathrm{n}=$ 54; $\sum \mathrm{xi}=2544 ; \sum \mathrm{xi}^{2}=120660 ; \sum \mathrm{yi}=2646 ; \sum \mathrm{yi}^{2}=130176 ; \sum \mathrm{xiyi}=125066$. Dengan menggunakan rumus uji validitas diperoleh $\mathrm{r}_{\mathrm{xy}}=0,631$.

Dari hasil perhitungan koefesien korelasi dengan teknik korelasi product moment didapat $\mathrm{r}_{\mathrm{xy}}$ sebesar 0,631 . Berdasarkan pedoman untuk interpretasi koefisien korelasi, maka koefesien korelasi sebesar 0,631 mempunyai tingkat pengaruh yang kuat, artinya terdapat pengaruh yang kuat antara insentif $(\mathrm{X})$ terhadap kinerja $(\mathrm{Y})$.

\section{Uji Koefisien Determinasi}

Selanjutnya analisis korelasi diteruskan dengan menghitung koefisien determinasi, yaitu dengan mengkuadratkan koefisien korelasi dan dikalikan $100 \%$. Jadi koefesien determinasinya adalah

$$
\begin{aligned}
& \mathrm{CD}=\mathrm{r}^{2} \times 100 \% \\
& \mathrm{~cd}=0,631^{2} \times 100 \% \\
& \mathrm{~cd}=0,40 \times 100 \% \\
& \mathrm{~cd}=40,0 \%
\end{aligned}
$$

Hal ini berarti bahwa varian yang terjadi pada variabel kinerja, $40.0 \%$ ditentukan oleh varian yang terjadi pada variabel insentif. Dengan kata lain, dapat disimpulkan bahwa $40.0 \%$ kinerja karyawandipengaruhi oleh insentif dan selebihnya sebesar $60.0 \%$ adalah ditentukan oleh faktor-faktor lain yang tidak diteliti disini.

\section{Uji Signifikansi}

Pengujian signifikansi dimaksudkan untuk mengetahui sampel yang diambil dapat digeneralisasikan terhadap populasi. Adapun rumus yang digunakan dalam uji signifikansi atau uji-t yaitu:

$$
\mathrm{t}_{\text {hitung }}=\frac{\mathrm{r} \sqrt{\mathrm{n}-2}}{\sqrt{1-\mathrm{r}^{2}}}
$$




$$
\begin{aligned}
& t=\frac{0,631 \sqrt{54-2}}{\sqrt{1-0,631^{2}}} \\
& t=5.864
\end{aligned}
$$

Nilai $t_{\text {hitung }}$ tersebut selanjutnya dibandingkan dengan nilai $t_{\text {tabel }}$. Dengan taraf signifikansi $5 \%$ dan derajat kebebasan $\mathrm{dk}=\mathrm{n}-2$ pada uji dua pihak (two tail test), maka dari tabel distribusi t diperoleh nilai sebesar 2.0063. Maka berdasarkan ketentuan: jika $t_{\text {hitung }}(5.864)>t_{\text {tabel }}(2.0063)$ maka hipotesis nol (Ho) ditolak dan menerima hipotesis alternatif $(\mathrm{Ha})$.

Adapun kurva pengujian dua pihak, seperti digambarkan dibawah ini:

\section{Gambar 4}

Kurva Uji Signifikansi Koefisiensi Korelasi Dua Pihak ${ }^{20}$

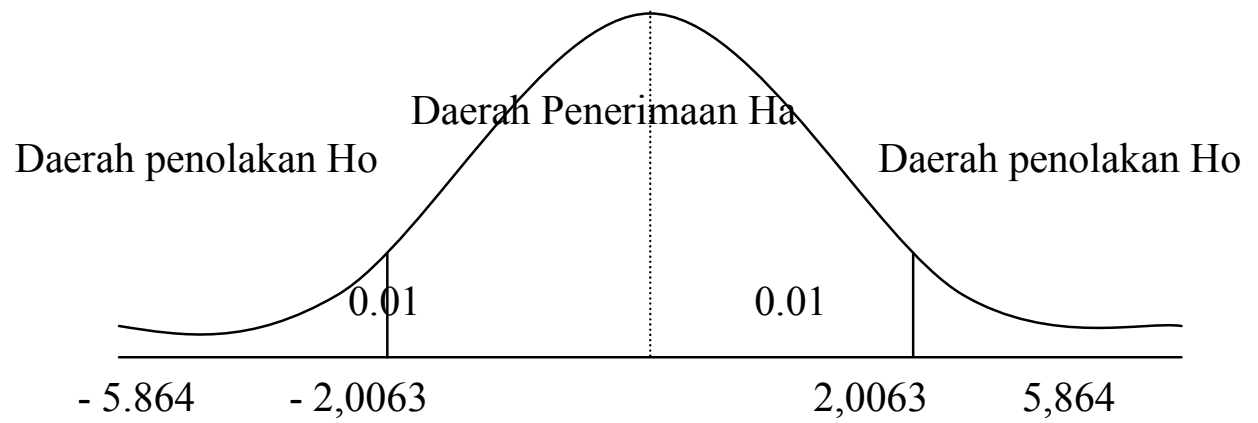

Dari gambar 4 di atas jelas terlihat bahwa titik nilai $t_{\text {hitung }}$ berada pada daerah penolakan Ho dan penerimaan hipotesis alternative (Ha). Jadi kesimpulannya koefisien korelasi antara insentif terhadap kinerja karyawan sebesar 5.864 adalah signifikan.

\section{Uji Regresi Linear Sederhana}

Hasil perhitungan regresi linier sederhana dapatdiketahui sebagai berikut, $\mathrm{n}=$ 54; $\sum x \mathrm{xi}=212.00 ; \sum \mathrm{xi}^{2}=837.92 ; \sum \mathrm{yi}=220.50 ; \sum \mathrm{yi}^{2}=904.00 ; \sum \mathrm{xiyi}=868.51$. Dengan persamaan regresi linier sederhana:

$$
\mathrm{Y}=\mathrm{a}+\mathrm{b} \cdot \mathrm{x}
$$


Menghitung nilai a dengan rumus:

$$
\mathrm{a}=\frac{(\Sigma \mathrm{yi}) \cdot\left(\sum \mathrm{xi}^{2}\right)-(\Sigma \mathrm{xi}) \cdot\left(\sum \mathrm{xiyi}\right)}{\left(\mathrm{n} \sum \mathrm{xi}^{2}\right)-\left(\sum \mathrm{xi}\right\}^{2}}
$$

$\mathrm{a}=2.10$

Selanjutnya dihitung nilai $\mathrm{b}$, dengan rumus berikut:

$$
\mathrm{b}=\frac{\mathrm{n} \Sigma(\mathrm{xiyi})-\left(\sum \mathrm{xi}\right) \cdot\left(\sum \mathrm{yi}\right)}{\mathrm{n} \Sigma \mathrm{xi}^{2}-\left(\sum \mathrm{xi}\right)^{2}}
$$

$\mathrm{b}=0,51$

Dari perhitungan di atas diperoleh nilai konstanta a sebesar 2.10 dan nilai koefisien regresi $\mathrm{b}$ sebesar 0,51 . Dengan demikian bentuk persamaan regresi linier sederhana adalah: $\hat{\mathbf{Y}}=\mathbf{2 , 1 0}+\mathbf{0 , 5 1} \mathbf{X}$

\section{Gambar 5}

\section{Garis Regresi Nilai Insentif (X) dan Kinerja (Y)}

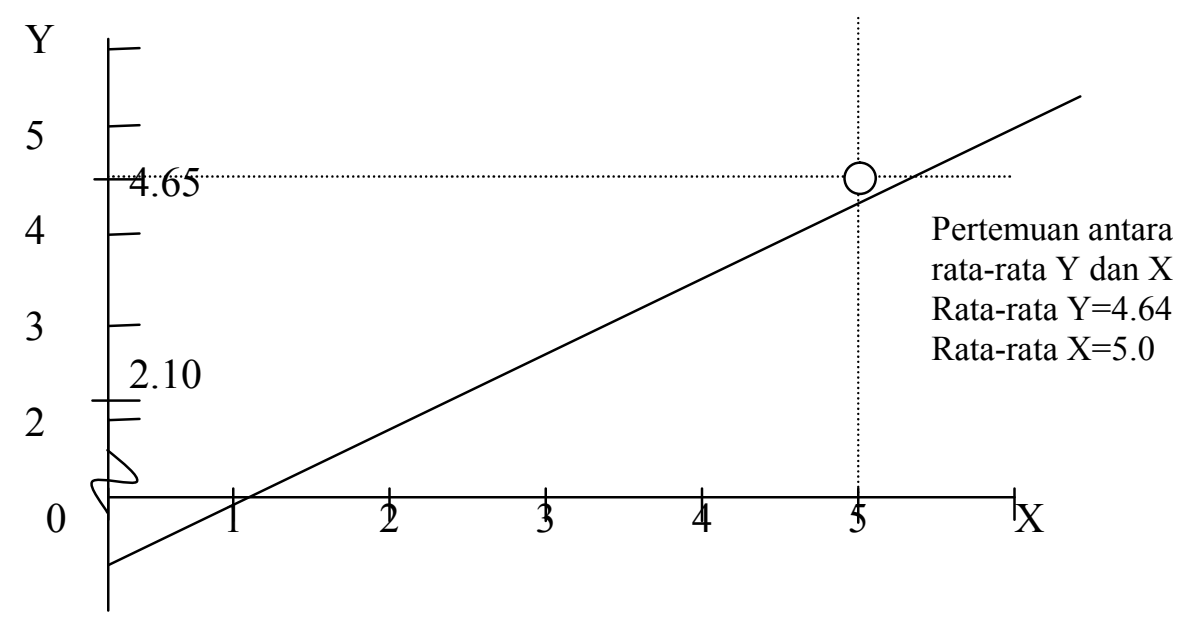

\section{Hipotesis Statistik}

Pengujian hipotesis yang dilakukan yaitu terhadap hipotesis nol $\left(\mathrm{H}_{0}\right)$ dengan satu hipotesis alternatif (Ha). Untuk itu sebelumnya dicari korelasi antara variabel $\mathrm{x}$ dengan variabel y, dengan rumus yang di gunakan adalah korelasi Product Moment. 
Dari data yang telah diolah maka dapat diketahui bahwa $\mathrm{n}=54 ; \sum \mathrm{xi}=2544$; $\sum \mathrm{xi}^{2}=120660 ; \sum \mathrm{yi}=2646 ; \sum \mathrm{yi}^{2}=130176 ; \sum \mathrm{xiyi}=125066$. Dengan menggunakan rumus korelasi product moment diperoleh $\mathrm{r}_{\mathrm{xy}}=0,631$ atau mendekati angka 1 .

Berdasarkan kriteria pengujian hipotesis dimana jika $r$ hitung $(0,631)>r$ tabel $(0,348)$ maka hipotesis nol $\left(\mathrm{H}_{0}\right)$ ditolak, dan menerima hipotesis alternatif $(\mathrm{Ha})$ dengan demikian pernyataan hipotesis yang diajukan terbukti benar bahwa"Terdapat pengaruh pemberian insentif terhadap kinerja karyawan".

\section{Kesimpulan}

Berdasarkan hasil penelitian dan analisis data di atas, penulis dapat mengambil kesimpulan bahwa berdasarkan analisis koefisien korelasi Product Moment $\left(\mathrm{r}_{\mathrm{xy}}\right)$ diperoleh angka sebesar 0,631 artinya memiliki korelasi yang kuat antara insentif terhadap kinerja. Sedangkan insentif memberikan kontribusi terhadap kinerja karyawan sebesar $40 \%$. Sisanya sebesar $60 \%$ ditentukan oleh faktor lain.

Dari hasil uji signifikansi yang telah dilakukan adalah $(5,864) t_{\text {hitung }}>t_{\text {tabel }}$ $(2,0063)$ pada taraf kesalahan $1 \%$ korelasinya adalah signifikan. Persamaan regresi linier sederhana yaitu $\hat{Y}=2,10+0,51 X$, artinya insentif mempunyai pengaruh terhadap kinerja karyawan sebesar 0,51.

\section{Catatam Akhir:}

${ }^{1}$ Malayu S.P. Hasibuan, Manajemen Sumber Daya Manusia, Edisi revisi, (Jakarta: PT. Bumi Aksara,, 2005), hal. 185 .

${ }^{2}$ Ibid., hal $185-186$.

${ }^{3}$ Ibid., hal. 186.

${ }^{4}$ Ibid.

${ }^{5}$ Veithzal Rivai, Manajemen Sumber Daya Manusia untuk Perusahaan: Dari Teori ke Praktik, Edisi 4, (Jakarta: PT.Rajagrafindo Persada, 20080, hal. 362.

${ }^{6}$ Sumber: PKB PT. LOC.

${ }^{7}$ Op. Cit., Manajemen Sumber Daya Manusia untuk Perusahaan: Dari Teori ke Praktik, hal. 364.

${ }^{8}$ A.A. Anwar Prabu Mangkunegara, Manajemen Sumber Daya Manusia Perusahaan, Cetakan ketujuh, (Bandung: PT. Remaja Rosdakarya Offset, 2007), hal. 67.

${ }^{9}$ Op. Cit., Manajemen Sumber Daya Manusia, hal. 94.

${ }^{10}$ Wibowo, Manajemen Kinerja, Edisi 2, (Jakarta: PT. Rajagrafindo Persada, 2008), hal. 7.

${ }^{11}$ Ibid., hal. 2.

${ }^{12}$ Hadari Nawawi, Manajemen Strategik, Cetakan kedua, (Yogyakarta: Gadjah Mada University Press, 2003), hal. 441.

${ }^{13}$ Op. Cit., Manajemen Kinerja, hal 4.

${ }^{14}$ Ibid., hal 76.

${ }^{15}$ Op. Cit., Manajemen Sumber Daya Manusia, hal. 87.

${ }^{16}$ Op. Cit., Manajemen Sumber Daya Manusia Perusahaan, hal. 69.

17 Ibid.

${ }^{18}$ Op. Cit, Manajemen Kinerja, hal. 226. 
${ }^{19}$ Sugiyono, Metode Penelitian Bisnis, (Bandung: Alfabeta, 2009), hal. 79-80.

${ }^{20}$ Ibid. hal. 184.

\section{DAFTAR PUSTAKA}

Hasibuan, Malayu S.P, Manajemen Sumber Daya Manusia, Edisi revisi, Jakarta: PT. Bumi Aksara, 2005.

Mangkunegara, A.A. Anwar Prabu, Manajemen Sumber Daya Manusia Perusahaan, Cetakan ketujuh, Bandung: PT. Remaja Rosdakarya Offset, 2007.

Nawawi, Hadari, Manajemen Strategik, Cetakan kedua, Yogyakarta: Gadjah Mada University Press, 2003.

Rivai, Veithzal, Manajemen Sumber Daya Manusia untuk Perusahaan: Dari Teori ke Praktik, Edisi 4, Jakarta: PT.Rajagrafindo Persada, 2008.

Robbins, Stephen P, Perilaku Organisasi, Jilid 1 edisi 8, Jakarta: PT. Prenhallindo, 2001.

Sastrohadiwiryo, Siswanto, Manajemen Tenaga Kerja Indonesia; Pendekatan Administratif dan Operasional, Jakarta: Bumi Aksara, 2002.

Sugiyono, Metode Penelitian Bisnis, Bandung: Alfabeta, 2009.

Suharyadi, Statistik untuk Ekonomi dan Keuangan Modern, Jakarta: Salemba Empat, 2010.

Wibowo, Manajemen Kinerja, Edisi 2, Jakarta: PT. Rajagrafindo Persada, 2008.

Mukhlishotul Jannah, dosen pada Fakultas Syari'ah dan Ekonomi Islam IAIN Sultan Maulana Hasanuddin Banten. 